\title{
Illusory identities and cultural hybridity among the "Sinoi" on Reunion Island
}

Between twenty and twenty-five thousand of the population are descendants of Cantonese or Hakka Chinese

\section{Live Yu-Sion}

\section{CpenEdition}

\section{Journals}

Édition électronique

URL : http://journals.openedition.org/chinaperspectives/650

DOI : 10.4000/chinaperspectives.650

ISSN : 1996-4617

Éditeur

Centre d'étude français sur la Chine contemporaine

Édition imprimée

Date de publication : 1 octobre 2003

ISSN : 2070-3449

Référence électronique

Live Yu-Sion, "Illusory identities and cultural hybridity among the "Sinoi" on Reunion Island », China Perspectives [En ligne], 49 | september-october 2003, mis en ligne le 17 janvier 2007, consulté le 28 octobre 2019. URL : http://journals.openedition.org/chinaperspectives/650 ; DOI : 10.4000/ chinaperspectives. 650

Ce document a été généré automatiquement le 28 octobre 2019

(c) All rights reserved 


\title{
Illusory identities and cultural hybridity among the "Sinoi" on Reunion Island
}

Between twenty and twenty-five thousand of the population are descendants of Cantonese or Hakka Chinese

\author{
Live Yu-Sion
}

\section{NOTE DE L'ÉDITEUR}

Translated from the French original by Jonathan Hall

1 Today, most of the Chinese descendants on Reunion have lost the central elements of their ancestral culture and no longer speak Cantonese or Hakka. In this article I propose to examine the question of cultural hybridity and the "return to our roots" among the Chinese descendants on Reunion, in connection with the problem of ethnic and cultural identity within a Creole society which has been mixed since its inception. On Reunion, actual social structures and interrelations are constantly traversed by a quest for underlying cultural identities. The latter are more a consequence of perception or accepted representations than of any grounding in reality, since all the different groups on the island have lost their ancestral language and culture over the last two, three or four generations. Their current Creole names, Sinoi (Chinese), Malabars (Tamils), Z'arabs (Muslims of Indian descent), Cafres (Madagascan Africans), Yabs (poor whites), Gro-blan (prosperous whites) have very few xenophobic or racist overtones; they are simply a legacy of colonial history within popular speech.

2 So what motives could lie behind the quest for identity, and what is the meaning of a "return to our roots" among the Sinoi, who call themselves and see themselves as Chinese in every respect? ${ }^{1}$ To begin to outline an answer to this question, it is necessary to recapitulate briefly the history of the Chinese immigrants to the island, and to give an account of their social and cultural organization. In addition, a greater 
understanding of this quest for "roots" is helped by considering the developments in the island's social and political context over the last two or three decades.

The island of Reunion is situated in the southwest area of the Indian Ocean, 880 kilometres east of Madagascar. It was uninhabited at the time of its discovery by the Portuguese in the early sixteenth century. Although it became a French possession in 1642 , it was only permanently settled after 1663. At first it was called Bourbon Island, but changed its name to Reunion in 1793, after the French Revolution. In 1946, its status was changed from colony to overseas French département ${ }^{2}$. Over its history of three and a half centuries, successive waves of migrants have settled there, these made up of settlers, colonialists, slaves, indented labourers, merchants, etc., from Europe, Africa, Madagascar, the Comores Islands, Asia and the Americas. At present, its mixed multiethnic and multicultural population amounts to 700,000 inhabitants.

A brief history and survey of the social organization of the Chinese on Reunion

The history of the Chinese on the island is well known in its broad outlines ${ }^{3}$. It was characterised by two kinds of immigration: contractual and so-called "free".

Contractual immigration

5 Contractual immigration began a few years before the abolition of slavery on Reunion in 1848. The turn to foreign labour to replace the slaves on the plantations was the main motive behind the recruitment of indentured Chinese workers. The first contingent of these workers arrived from Malaya, and not directly from China, in 1844. These men were intended to work on the land, on building dykes and banks, or in grain production. But in 1846, the colonial government halted the recruitment of Chinese, considering them to be "bad workers" following a number of revolts and other acts of violence by a number. Living and working conditions on the plantations were hardly any different from those borne by the Madagascan and African slaves, since the main motives of the masters or the plantation owners were profits at any price.

\section{Chinese Population size}

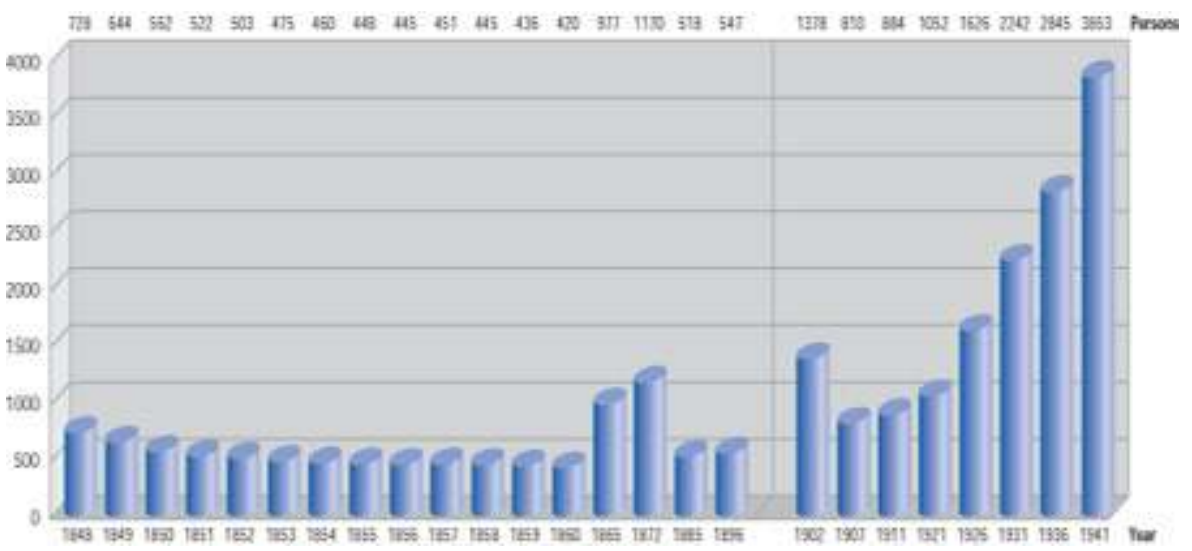

Sources: 1848-1860: ADR 6 M, Population et Statistiques and De la Barre de Nanteuil, Législation de l'île de la Réunion, Editions Donnaud, Paris, 1861, p. 388, 1865-1896 : Annuaires de l'île de la Réunion : 1902-1941 : ADR 6 M, 1296, Population et Statistiques, and censuses.

6 In 1901, a second attempt to make use of a shipment of 808 Chinese from Fuzhou in China, met with the same failure as the first. The Chinese refused to accept the conditions of virtual slavery. They denounced their plantation bosses' failure to honour the terms of their contracts and the harsh conditions which they imposed. Nearly all of 
them left the island in 1907, as a consequence of the disturbances they caused on various plantations.

These first two waves of immigration provide little by way of sociological interest for the study of ethnic Chinese on the island, however, since most of them left at the end of their contracts, and some even before. The present day Sinoi are the result of twentiethcentury Chinese immigration.

Free immigration

8 The so-called free Chinese immigration to Reunion began after a law was passed in 1862, which allowed any foreigner to take up employment there. Every year several hundred Chinese from the southern provinces (Guangdong) left their home villages for Reunion (see insert). Between 1920 and 1940 their numbers steadily rose to several thousand and over. Some came to rejoin their families, while others were driven by events like the Sino-Japanese war (see insert). In 1946, the laws and regulations concerning immigration into metropolitan France became applicable to Reunion, which had become an overseas French département. After 1950, Chinese immigration practically ceased, because of the closure of China's borders. At present, the great majority of Chinese on the island are descended from the voluntary migrants, and not from the indentured workers of the nineteenth century.

Language groups

9 There are only two Chinese language groups on the island, Cantonese and Hakka. The Cantonese were the first to arrive, beginning in 1880 , from the villages around the city of Guangzhou, Nanhai, Shunde and Shajiao. They generally settled in the northern part of the island, in Saint-Denis, Saint-André and Saint-Benoît. However, around 1850, other Cantonese immigrants began to arrive from Mauritius ${ }^{4}$.

10 The first Hakkas arrived from Meixian or Mauritius from the second half of the 1880s. A few years later, more arrived from the French territories of South-East Asia (Indochina). They settled in the south of the island (Saint-Pierre and Le Tampon), probably because of the commercial rivalry and long-standing divisions between them and the Cantonese.

Population size

11 The Chinese represent a very small percentage of the overall population on Reunion. In the nineteenth century, there were less than a thousand, but between 1900 and 1950 the figures rose from 1,000 to 4,000. However, the frequency of migratory movements between Mauritius, Reunion, the Seychelles and Madagascar prevents any precise assessment. Currently the "Chinese" population of the island is reckoned at between twenty and twenty-five thousand. But exactly who counts as Chinese on Reunion?

The uneven proportion of Chinese women and men

Reunion provides yet another example of a characteristic specific to Chinese emigration overseas. At the beginning there was generally a disproportionate number of men and women. Just as in France ${ }^{5}$ or elsewhere, such as Madagascar ${ }^{6}$, Tahiti ${ }^{7}$ or Mauritius ${ }^{8}$, the majority of the early immigrants were men alone, with their wives only joining them a few years later. The first Chinese women reached Reunion in 1864, but there were only nine of them. From 1864 to 1902, their number never rose above a hundred. It was only after 1920 that numbers took off: 105 in 1921, 277 in 1926, 466 in 1931, 616 in 1936, and 1,183 in $1941{ }^{\circ}$. Before the Second World War, the distance from their native land inhibited their relocation to the island, owing to the risks and high 
cost of sea travel. In addition, the weight of tradition in China offered few incentives for Chinese women to emigrate, since their departure would deprive the family of its chances for having descendants, threatening it with the disappearance of its lineage.

The different Chinese social groups

13 The historical record of Chinese immigration to Reunion enables us to make a current distinction between five separate groups of Chinese or Sinoi, to use the Creole term for people of Chinese descent ${ }^{10}$.

14 The first group consists of immigrants who were born in China. They speak Chinese, with a bit of Creole and a smattering of French. They form a small minority of immigrants who have been there since the inter-war years (1920-1940). They are mostly restaurant owners and shopkeepers, because commerce was at that time one of the quickest means of economic and social integration.

The second group consists of their descendants born before 1945, who were educated and brought up in Reunion society but with little exposure to the French educational system. In many cases, they attended a Chinese school, and they have assimilated some aspects of Chinese and Creole culture but little by way of French culture. They have a poor command of French, but they speak Chinese and Creole fluently and do not experience any deep sense of crisis in cultural identity. Some of them took over the family business after the death of their father, while others entered various firms on the island as salaried employees or labourers. Since the 1970s, the social and economic changes on Reunion have led to a rise in their standard of living. Year by year, the Chinese shops have turned into more spacious and modern businesses like self-services or mini-marts.

The third group consists of those born after the 1950s and educated in French. They no longer speak Chinese, apart from a few phrases, and only use Creole to talk to their parents or their immediate circle. Most of them underwent higher education in France in the 1960s and 1970s, and have entered the liberal professions (as doctors, dentists, architects, lawyers, etc.), the large private firms (as accountancy experts, engineers, traders), or the public sector (as administrators, and teachers). Their feelings of belonging to the Chinese community remain relatively strong. This generation is to a great extent assimilated into French culture, but for about twenty years they have been trying to "get back to their roots" through an attempted re-appropriation of some salient aspects of Chinese culture (courses in the Chinese language, calligraphy, tai chi, qigong, and Chinese cooking). This group experiences moments of identity crisis.

The fourth group is composed of young people born after 1975. This generation is the most integrated into French or Western cultural patterns. Nonetheless, some of them are attempting a return to their Chinese cultural identity (trips to China for recreation or study, Chinese language courses, martial arts training, a taste for Hong Kong cinema). Their sense of belonging to the Chinese "community" is also relatively strong. But some of them totally reject their Chinese origins and culture, without any major identity crisis.

18 The last group consists of people of mixed descent who no longer have any knowledge of the Chinese language or culture. This hybridity, recent or not, of a fringe sector of the Chinese population is noticeable above all in the physical appearance of different individuals. It can happen that their dominant physical characteristics do not correspond to their Chinese surnames. A person from Reunion with a Chinese surname may look like a Creole, a Madagascan, a Tamil, or a Caucasian. Quite a number within 
this group, at a certain point in their lives, try to rediscover their Chinese origins (by setting up associations, travelling to their ancestral villages, organising or joining in traditional feasts, regularly visiting pagodas, reading Chinese stories in Creole translation, etc.).

The formation of a Chinese cultural identity

The process whereby the multicultural identity of the Chinese, or rather the Sinoi, has been formed only affects those generations born on Reunion, since the first generation were born and raised in China, only coming to the island as adults. This formative process involves the assimilation of several cultural elements whose provenance is partly Creole, partly Chinese and partly French, so the identity of these islanders of Chinese descent is actually tricultural. The multiethnic, multilingual and multicultural social context gives rise to a culture of hybridisation which is apparent everywhere, whether in cultural creations like music, buildings, art and literature, or in institutions, implements, artefacts, etc. Hybridisation is a process of adoption, appropriation and remoulding of disparate cultural elements ${ }^{11}$. It only takes root in certain kinds of society or environment. Caught up in a permanent confrontation of different languages, beliefs and philosophies, the cultural interplay on Reunion is a long-term mechanism of acquisition, integration and acculturation of certain elements which become reformulated, reinterpreted and redefined to give rise to a new identity. However, as Laplantine and Nouss point out, hybridisation "is not manifested in a constant or consistent fashion, but develops through slippages and alternation. Hybridisation is detectable in movements of inner tension and patterns of resonance and oscillation, finding expression through provisional forms organised in alternative ways". This non-linear movement "is a trajectory which advances in spirals, enveloping, developing, redeploying and above all displacing, the components of literature, music, cooking and languages ... from one cultural space to another" ${ }^{12}$.

The Creole component

The cultural identity developed by generations of Chinese born on the island must be seen in its particular social context. This was characterised by a relatively long period of isolation, since Reunion was somewhat "forgotten" by metropolitan France during the first three centuries of its existence (from 1663 to 1965). Until the late 1960s, it remained underdeveloped. There was little in the way of schools, hospitals or public housing, and the road system was very limited and largely without tarmac. The health levels on the island were low, and infectious diseases like malaria continued to afflict a considerable portion of the population. This situation began to improve from the 1970s, with the introduction of free medical care, social security and the establishment of the Departmental Directorate for Health and Social Affairs (DDASS). The long isolation due to distance provided the context in which different cultures from all over the world could meet, exchange and intermingle. This interpenetration of languages, religions and philosophies gave birth to a hybridity which nowadays has acquired its own identity. The island's Creole is the outcome of a linguistic brew of French with African, Asian and Madagascan languages. It has become the mother tongue of all the inhabitants, the lingua franca of the large majority of the population, with the exception of the new arrivals from metropolitan France.

21 All the generations of Chinese born on the island are steeped in Creole culture, despite certain claims to the contrary. This is because society puts forward cultural models, defining norms and values which the individual interiorises from the moment of his 
birth. In a multiethnic and multicultural society, an individual identifies with several groups, considering himself a member of them all as a given fact, but at the same time he feels different from the other members of these groups, when they call themselves Chinese, Tamil, Madagascan or whatever. In short, the individual is caught up in the dialectic of self and other. This also involves a reciprocal articulation of the factors of permanence and change. The development of Chinese identity follows this evolutionary process, progressively moulding and modifying itself, and adopting different forms throughout its existence in response to the events and disruptions in the social, political, cultural, or economic life of the island. In short, the Chinese, or rather the Sinoi cultural identity develops in accordance with the transformations affecting the whole of society on the island.

The Chinese component

Apart from the fundamental role played by the Chinese family in the education of children, the social and cultural organization of the Chinese rests on community institutions, such as associations, places of worship and schools. Their first cultural associations were set up by the Cantonese in 1877 in Saint-Denis. These were of two types. One was based on the clan principle, meaning that they were frequented by individuals bearing the same clan name and coming from the same home district. The others were regionally based, bringing together migrants from the same village or home district who were not from the same clan ${ }^{13}$. Formerly, these associations played a role in preserving and disseminating the cultural heritage. Their activities were focused on making the younger generation aware of Chinese culture through organising language or cookery courses, traditional festivities, or encouraging people to get together through sports like table tennis, football and basketball, or through group outings, dances or banquets.

The first Chinese school was founded in 1927 in Saint-Denis. But it closed in 1930, because the teacher returned to China ${ }^{14}$. The organisation of the Chinese schools was the responsibility of the Chinese chamber of commerce which financed them through contributions from businessmen. The schools paid teachers from Mauritius or China, and the language of instruction was Hakka in the Hakka schools, and Cantonese in the Cantonese schools. The Chinese schools which were set up in the inter-war period were dissolved just after the Second World War by the colonial authorities who were trying to eradicate all cultural characteristics other than French ones. The colonial administration saw in such schools elements of cultural separation, and set out to control them by demanding that there should be less time spent on Chinese than on French language teaching. It was in order to comply with the new regulations that the Chinese had to set up bilingual Franco-Chinese schools. The first of these opened in Saint-Denis in 1942. This school and the one in Saint-André, are the best known. They cater to about $80 \%$ of Chinese youngsters born on the island ${ }^{15}$. After the Second World War, with Reunion becoming an overseas département, children's education in French schools became compulsory. In addition, their parents saw no point in putting them through a Chinese education, having abandoned all hope of returning to China. The generation born in the 1950s went to French primary and secondary schools.

The French component

24 From the time of the earliest settlement up until the 1960s, French cultural influence on the majority of the population was relatively slight, on account of the geographical distance. It was only after Michel Debré, a native of metropolitan France, was elected as 
deputy in 1963 that there was a policy of assimilation tending to eliminate the Creole language and culture. Nevertheless, this political representative did establish a development policy for the island, and created the necessary infrastructure (schools, hospitals, roads, airports) to bring it out of its isolation.

Schooling was one of the instruments of this Frenchifying policy. The elite had already established a lycée for their children, and for a long time this institution was the only means of social advancement for the youth of the island. For the rest of the population, the authorities had set up junior colleges and technical schools. There were also private schools run by religious orders. At present Reunion possesses a large number of junior colleges and lycées, and one university serving 12,000 students.

In addition, the introduction of television has brought the island into contact with the rest of the world, and opened the inhabitants' insular outlook. The island can now receive several satellite channel offerings, and this has brought profound changes into daily life and transformed the islanders' way of thinking. One consequence of this inflow of images from overseas has been an identification with the lifestyles in metropolitan France.

Over the last two decades, the socio-economic changes on the island have led to a rapid evolution of society from being a typical colonial society towards becoming a consumer society. This is evident in real facts as well as in the signs and symbols common to all such societies: there has been a huge expansion of services and material goods, of mass communications, and of growth in individual spending, coupled with a spread of the myths of equal rights to the good life, etc. ${ }^{16}$.

Cultural loss

The assimilation of the different components of Creole, Chinese and French culture by the later generations of Chinese confronts the third generation with an identity problem. Its intensity varies with the individual involved, but the post-war youth share a disquiet over their identity. Having undergone a process of veritable deculturalisation from the 1960s to the 1980s, they are now attempting to recover their roots. In that earlier period the Chinese language and culture were so devalued that the younger generations were ashamed of being Chinese.

Now, however, they are living out a paradoxical situation. They acknowledge themselves as Chinese, or of Chinese descent, and they are considered as such by the society of the island at large, but they have neither Chinese language nor Chinese culture. Their lingua franca is Creole, but they do not feel themselves to be Creole or French, and they hardly ever participate in any Creole or French cultural activities. The search for identity is not an issue for people of Chinese descent alone, for it affects the whole post-war generation in general, who are clearly abandoning their native tongue in favour of French. Christian Barat notes that, from colonial rule to rule via the département, there is an ongoing process of assimilation into the reputedly "universal" French language and culture, and this actually imposes an increasing measure of integration into the social, economic and cultural sphere of metropolitan France and the West in general. This assimilation process, he writes, "brings to the islanders the benefits of an opening onto the outer world, but at the same time it imposes on them the control of monopolies over the different means of communication (from mass media to airlines) and their corresponding consumer models" ${ }^{17}$. In a work published a few years earlier, Jean Benoist had already highlighted how "the process of assimilation has operated without interruption until the present day, and has induced the 
inhabitants of Reunion to overvalue French cultural models and standards, which are then taken as a benchmark and source for imitation, while also serving as a measure by which other cultures must be downgraded" ${ }^{18}$.

Back to Chinese roots François Mitterand took office in May 1981. The law on decentralisation, which was passed on December 31st 1982, gave Reunion a collective territorial status. In other words, some decision-making powers were entrusted to locally elected people. This decentralisation helped to bring about changes in certain aspects of political, economic and social life: independent radio stations, commemoration of the 1848 abolition of slavery, creation of the Réunion Academy and University, etc. This policy also encouraged the development of Tamil, Chinese, Comoran, Madagascan and Breton societies ... who all proclaimed their right to a distinct identity and a return to their roots. In the words of one of my informants, "On their return from their higher education in France in the 1980s, the third and fourth generation Chinese believed that their own language and culture had been distorted by the pressure to become French. In order to counteract this assimilation, they went back to their "roots", visiting their ancestral villages to meet up with members of their family and rediscover some traditional Chinese cultural values .... People of the third generation, whose parents had rejected their Chineseness, turned back to Chinese culture. Many have that aspiration. ... There have been times when I too have asked myself whether I am Chinese, French or Reunionese. But to be frank, I only asked that when I was twenty, and I don't any more. I am in France, and I may not be like the French but, as long as I'm accepted here, I no longer ask questions like that. Some of my friends of my age do have a problem, though. It's a kind of intellectual need. often people like that feel rejected and can't adapt to life in France ..."

This desire to recover one's origins finds an outlet in the cultural celebrations which the islanders of Chinese descent organise on traditional feast days like the festival of Guandi or the Lunar New Year. The return to their "roots" is found most frequently among young people who have studied in France. One of them, Karine, told me, "It was in Paris that my Chinese side, my identity, came out more. In Paris there is a large Chinese community that I don't feel very close to. On the other hand, in my professional life, there are many Asians, Japanese, Koreans, and so forth. But what made me more aware of my Chinese identity was the way other people looked at me, and their questions, like 'Who are you? Where do you come from? Can you speak Chinese?'. And who were these other people? They weren't only the French, but also the Koreans, the Taiwanese, the Japanese, the Germans, the Italians ... the people I work with". 

its unfamiliarity with the real meanings of all the Chinese cultural references, due to its assimilation of French and Creole values. So the cultural activities mentioned above remain purely episodic. Furthermore, daily life is carried on in the context of Reunionese, not Chinese society. The will to become Chinese again turns out to be an illusion. This desire to enrich their Chinese linguistic and cultural heritage through a recovery of their origins has produced no positive results. At the same time, within the context of the hybridity which characterises the whole of Creole society, the issue of Chinese cultural origins remains in many ways rather problematical. The quest for origins is directed towards a largely mythical territory, because the China of the 1930s and 1940s, which their parents or grandparents knew before leaving, has now disappeared. As Michel A. H. told me, "All my family members who have had a bit of free time have visited China at least once or twice. But they have realised that the China of their parents no longer has anything to do with them, that the differences are too big. For most of them, their lost dream was that of an individual from our Creole and French culture. They no longer feel any real sense of contact with Chinese culture". Intercultural contacts via the look of others

In the field of intercultural contacts, the question of individual ethnic and cultural origins is a constant factor, inasmuch as it is the phenotype, that is to say the physical features, which allows the individual to be recognised as belonging to one group or another. The family name also serves, together with the colour of eyes and skin, and the type of hair, as a sign of membership of a particular group. The inhabitants of Reunion identify themselves, and make the corresponding distinctions between themselves, through such socially established representations. In contemporary speech, there are seven such different groups.

The French from metropolitan France are called the Zoreils. They have earned this label because, when they are still new arrivals and are addressed in Creole, they tend to strain forward with their ears (les oreilles), trying to understand. The Tamils are called the Malabars through a misunderstanding, because they were thought to have come from the Malabar coast (to work in the plantations). The Gujerati from India are called the Z'arabes because they are Muslims (having settled as merchants on the island since 1870). The mixed race people of African origin are called Cafres. They are the descendants of slaves from Mozambique, Guinea, Senegal, or Madagascar, but not from Caffraria in South Africa. The white Creoles make up the population of European origin and are subdivided into two groups: the Gro-Blan are the former owners of the sugar plantations, and the $Y a b$ are the poor whites who settled in the Hauts de la Réunion area. The Chinese are called Sinoi in Creole, and this term serves a meaningful function, since it enables a distinction to be made between the Chinese (Chinois) from China and those who were born and raised on the island.

All these assignments of ethnic identity are the products of looking. To give an individual a name which both particularises and classifies is an essential stage in the way the islanders are assigned to a particular group. This naming is closely linked to another aspect of identity, namely the one which determines his ethnic, rather than his cultural group identity. But while ethnic identity is perceived in terms of a person's hereditary traits, it is also expressed through a range of signs and symbols, including the family name, which are acquired at birth. The family name is both a sign, a marker of origins, and a symbol of filial descent. It functions both to classify the individual's

China Perspectives, 49 | september-october 2003 
identity and to attach it to a lineage, but it also anchors it to a region, a country, and hence to a social status.

In order to clarify their geographical provenance, overseas Chinese often refer to the town or village where they or their ancestors were born. The family clan's place of origin is a basic factor. According to Norbert Elias, the family name is for the individual "both the outward symbol of his uniqueness and the means whereby he answers the question of who he is, in his own eyes and in the eyes of others" ${ }^{19}$. The individual acquires membership of a particular lineage or territorial group through certain distinguishing attributes (names, or other external signs) and these become the marks of his identity, notably in the form of an attachment to a particular territory or cultural formation, thus becoming the definitive agencies in ethnic and cultural identity formation.

The following personal statement shows, however, that this general schema does not always fit the reality on Reunion: "My grandmother is a Creole of mixed Cafre (AfroMadagascan) and Malabar (Tamil) ancestry. My father was much lighter skinned and did not have Chinese eyes. My sister is very light-skinned, and she has a light-skinned daughter who does have Chinese eyes. As my sister's complexion is so light, her children are practically white. My brother has Chinese eyes and slightly Cafre hair. But I have Chinese hair, but not Chinese eyes. So all of us children have a bit of Chineseness, in our eyes, hair or skin. My mother is a Cafre (Afro-Madagascan) in appearance. As for me, I have two children. My son has a face like mine, but a slightly lighter complexion. My aunt has four children-three girls and a boy. One of the girls has turned out completely Chinese, with straight hair ... One evening, in a family gathering there were only Chinese there, I mean, everyone looked Chinese, except me. There were also three girls who looked rather more Creole, of the yab (poor white) sort. Talking it over then, we wondered about our origins and realised that we shared Chinese origins. There was also somebody there who went to school with me, and to look at him you'd say he was a yab, but he had a Chinese family name."

The operative perceptual schema here characterises an individual according to the stereotypes, prejudices, and normalising expectations fixed by society. These identifying attributes belong to the realm of social representations. But often they do not correspond to an individual's actual cultural identity. The Norwegian anthropologist, Fredrik Barth was the first to propose that we give up analysing ethnic questions in terms of a group's ethnic, cultural or historical features ${ }^{20}$, since ethnic and cultural identity-which some writers call ethnicity - are not fixed and unchanging facts, but dynamic processes which undergo transformations. Barth is more concerned with the forms of group organisation than with their culture and its correlates, which invariably include paradoxes and inconsistencies. In his view, the culture of a group is secondary, and it does not constitute an essential element defining its identity. Instead, he invokes the symbolic demarcations between groups, which he calls ethnic boundaries. Groups construct these boundaries, and then raise them as barriers, to mark themselves out as different from other groups. In other words, they define themselves through their relationship to others: "Ethnic distinctions ... are the consequence of the phenomena of assignment and attribution, through which groups, related oppositionally to other groups, define and proclaim their own identity" ${ }^{21}$. Insofar as an ethnic group recognises an individual as a member, and the individual feels himself to be a member, his identity will turn out to be characteristic of the group. Barth points 
out that the role of "ethnic leaders" in mobilising and laying claim to group identities should not be forgotten. In his view, such leaders may be aiming at the politicisation of group identity, which often has nothing to do with the popular will and culture of the groups themselves. This thesis is borne out by the behaviour and the attitudes of people of Chinese descent on Reunion.

The permanent contact and daily social interchange between the third and fourth generation Chinese and the other "ethnic" groups on Reunion have created a cultural hybridity which is the cultural basis of society on the island. This means that there are no truly distinct ethno-cultural communities there. About twenty years before Barth's observations, Robert Chaudenson had already drawn attention to this cultural hybridity when he wrote that "the process of group integration ... goes back so far, and was so rapid and wide-ranging that it is now more or less impossible to detect a clearcut identity in any group whatsoever, in terms of either ethnicity or anything else. The only exceptions to this are the very small minority of homogeneous communities composed of recent immigrants, such as the Chinese, or Muslims from India" ${ }^{22}$. I can only partly agree with this view, because the Chinese and the Indian Muslims in no way constitute "communities" in the sociological sense ${ }^{23}$, and still less "homogeneous communities". The ethnic group names in place (cafres, malabars, zoreils, yab, sinoi ...) are the products of established ways of looking. They are the result of mental constructions of difference and have nothing to do with the social realities of the ethno-cultural groups on the island. Cultural practices like the traditional feasts (Guandi, Lunar New Year, Dipavali) are potential seeds from which an identity is made to appear. They are perceived as means for the cultural production of the ethnicity of this or that group.

Nowadays the so-called cultural associations are no longer institutions for the preservation and dissemination of Chinese culture, as the pre-war associations were. Their activities are limited to organising outings (tours, picnics, restaurant visits), setting up courses in Mandarin (whereas the great majority of the Chinese "community" are of Hakka or Cantonese origin), or encouraging social contacts among the younger generation through dances and banquets. In a predominantly Creole, hybridised social context, cultural references proliferate everywhere, blurring the outlines of the original ethnic and cultural identities, which then become purely a matter of interpretation. So these references become elements which sustain a purely illusory sense of identity. The supposed state of belonging to a world of Chinese culture has no connection with reality, and is nothing but an empty fantasy. Creole still remains the lingua franca of these Chinese, being the language in which they communicate most naturally in their day-to-day life. The most obvious cultural elements of their plural identity are the languages which they use everyday (Creole, French, as well as Chinese). So their identity is likewise multicultural. To be Chinese in a Creole society is to belong to two, or even three, cultural worlds (Chinese, French and Creole).

The "return to cultural roots" with its turning back to origins, is partly linked to a resistance to the policy of French assimilation on the one hand, and to the merging into Creole on the other. It is a response to the devaluation of the Chinese cultural view of the world. Some of its adherents consider that Creole culture cannot equal the prestige of Chinese culture, which they see as remarkable for its depth and its antiquity. So for them hybridity represents a loss of identity and worth. 

opposition to their surroundings indirectly express their pain (often very close to the surface) at living amidst several cultural milieux. Such reactions reveal an inner suffering, which is full of paradoxes and contradictions, but which is one of the consequences of all the expression of concern with identity since the mid-1980s (the policy of French assimilation is another). Meanwhile, however, those in pursuit of this "quest" for origins are in reality right in the middle of the Creole society to which they actually belong. It is in this sense that Barth's reflections on "ethnic leaders" is applicable to the analysis of the Sinoi which I am presenting here.

As a post-colonial multicultural society, Reunion is still partly living in its colonial inheritance, and it is not free of the stereotypes and old prejudices shared by all the islanders, whether of Chinese, Tamil, Gujerati, Madagascan, Comorian or European origin. This multiculturalism deserves greater attention, but that has not been the aim of this article. Here I have approached the question of the identity of the Chinese descendants on Reunion in terms of their interrelationship with the ways that the other groups on this island in the Indian Ocean have also constructed their identity.

\section{NOTES}

1. Whatever their degree of biological or cultural hybridity, and whichever generation of immigrants of Chinese origin they may belong to, I use the term "Chinese" to designate those who have kept their language and culture, and "Sinoi" for those who have largely lost them. See my article, "Chinois et Sinoi à la Réunion: diaspora et ethnicité" in Migrations-Société, No. 6, November-December 1997.

2. Département d'outre-mer ou DOM.

3. See Durand, Dominique and Hin-Tung, Jean, Les Chinois de la Réunion, Australe Editions, Capetown 1981; Wong Hee-Kam, Edith, La diaspora chinoise aux Mascareignes: le cas de la Réunion, Université de la Réunion/L'Harmattan, 1996; Live Yu-Sion, “The Overseas Chinese in Reunion Island", Encyclopedia of Chinese Overseas, Singapore, Chinese Heritage Center Publications, 1999; Helly, Denise, "Des immigrants chinois aux mascareignes" in Annuaire des Pays de l'Océan Indien, 1976, Vol. 11l, pp. 103-124.

4. Ly Tio-Fane, Huguette, La diaspora chinoise dans l'Océan Indien occidental, Aix-enProvence, Greco-Océan Indien, 1981, p. 151.

5. Live Yu-Sion, La diaspora chinoise en France: immigrations, activités économiques et pratiques socioculturelles, doctoral thesis in sociology, École des Hautes Études en Sciences Sociales, Paris 1991, 2 vols., 824 pp.

6. Slawecki, Léon, French Policy towards the Chinese in Madagascar, Hamden, The Shoe String Press, 1971.

7. Coppenrath, Gérard, Les Chinois de Tahiti, de l'aversion à l'assimilation, 1865-1966, publication of the Société de Océanistes, Musée de l'Homme, 1967.

8. See Ly Tio-Fanne, Huguette, op. cit.

9. Wong Hee-Kam, Edith, op. cit., p. 93.

China Perspectives, 49 | september-october 2003 
10. I prefer to use the idea of a "group" rather than a "generation". The former designates a collection of individuals with certain socio-cultural characteristics in common, while the latter is only useful insofar as one generation of immigrants engenders a second or third one-whose parents no longer share the same cultural background.

11. For references to hybridity and creolisation see Bastide, Roger, Les Amériques noires, Paris, Payot 1967; Bonniol, Jean-Luc, La Couleur comme maléfice, Paris, Albin Michel 1992; Bonniol, Jean-Luc, Paradoxes du métissage, Paris, Éditions du CTHS 2001; Benoist, Jean, "Le métissage, biologie d'un fait social, sociologie d'un fait biologique", in Métissages, Vol. 2: Linguistique et Anthropologie, Paris, L'Harmattan 1992; Gruzinski, Serge, La Pensée métisse, Paris, Fayard 1991; Toumson, Roger, Mythologie du métissage, Paris, P.U.F. 1998. 12. Laplantine, F and Nouss A, Métissages, Paris, Éditions Pauvert, 2001, pp. 8 and 11. 13. See Wong Hee-Kam, Edith, op. cit., p. 13.

14. See Huaqiaozhi Liuniwangdao (Annals of the Chinese on La Réunion) Huaqiaozhi Bianzhuanweiyuanhui, Taipei, 1960.

15. See Durand D. and Hin-Tung J. op. cit., and Wong Hee-Kam op. cit.

16. See Live Yu-Sion, “Sociologie de la Réunion: mutations, paradoxes, représentations, migrations", in conference proceedings: Vingt ans d'anthropologie à la Réunion, Université de la Réunion/L'Harmattan, Saint-Denis, 1997.

17. See Barat, Christian, À la découverte de la Réunion, Vol. 8, Capetown, Favory 1980.

18. See Benoist, Jean, Un développement ambigu, Saint-Denis, Fondation pour la recherche et le développement dans l'Océan Indien 1975 (reprinted 1983).

19. Elias, Norbert, The Society of Individuals, Oxford, Blackwell 1991 (orig. 1987).

20. Barth, Fredrik, Ethnic Groups and Boundaries, Bergen, Universitetsforlagest, Oslo, French trans. by Bardolph J., Poutignat Ph. and Streiff-Fenart in Théories de l'ethnicité, Paris, P.U.F. 1995.

21. Barth, Fredrik op. cit., p. 205.

22. Chaudenson, Robert, Les Créoles français, Paris, Nathan, 1979, p. 32.

23. Tönnies, Ferdinand, Communauté et Société: catégories fondamentales de la sociologie pure, Paris, P.U.F, 1944, republished by Retz/CEPL, Paris 1977; Granovetter, Mark S., "The strength of weak ties", American Journal of Sociology, No. 78, 1973, pp. 1360-1380: Granovetter, Mark S., "The strength of weak ties: a network theory revisited" in Marsden, P. V. and Lin, N. (eds.), Social Structure and Network Analysis, Beverly Hills, Sage 1982; Wellman, Barry, and Berkowitz, S. D., Social Structure: A Network Analysis, Cambridge, UK, C.U.P, 1988. 